\title{
ANALISIS KINERJA BPSPAMS TIRTO SUMBER MULYO SEBAGAI PERTIMBANGAN MENJADI UNIT BUMDES DI DESA MIJEN KECAMATAN KEBONAGUNG KABUPATEN DEMAK
}

\author{
Astohar $^{1 *}$, Dhian Andanarini Minar Savitri ${ }^{2}$, Yuyun Ristianawati ${ }^{3}$, dan Prihansantyo \\ Siswo Nugroho ${ }^{4}$, \\ 1,2,3,4 STIE Totalwin \\ astohardemak@gmail.com
}

\begin{abstract}
ABSTRAK
Badan Pengelola Sarana Penyediaan Air Minum dan Sanitasi (BPSPAMS) Tirto Sumber Mulyo Desa Mijen merupakan salah satu dari BPSPAMS yang ada di Kecamatan Kebonagung yang mempunyai tugas sebagai pengelola air dan sanitasi di tingkat desa. Dalam pengelolaan sarana air dan sanitasi ditingkat desa perlu dinilai kinerja untuk dapat dievaluasi tindak lanjut kedepannya untuk strategi ataupun posisi dari kelompok pengelola tersebut yang sudah masuk dalam unit Badan Usaha Milik Desa (BUMDes) Maju Lancar. Standar penilaian kinerja ini menggunakan standar penilaian kinerja dari Juknis Pengelolaan SPAMS tahun 2020. Hasil penilaian kinerja menunjukkan bahwa secara umum kinerja dari BPSPAMS Tirto Sumber Mulyo dalam kategori sedang. Secara parsial menunjukkan kinerja pada perencanaan dalam kategori rendah, pada administrasi dan keuangan berkinerja tinggi, pada kinerja layanan air minum dan sanitasi dalam kategori sedang serta untuk kinerja dari kemitraan dalam kategori rendah. Harapan kedepan untuk peningkatan kinerja BPSPAMS bersama BUMDes Maju Lancar perlu berkolaborasi atau menigkatkan kerjasama dengan pihak - pihak eksternal seperti pihak akademisi, praktisi serta institusi pemerintah yang dapat meningkatkan keuntungan dan manfaat bagi masyarakat.
\end{abstract}

Kata Kunci : Perencanaan, Administrasi, Keuangan, Layanan dan Kemitraan

\begin{abstract}
BPSPAMS Tirto Sumber Mulyo Mijen Village is one of the BPSPAMS in the District Kebonagung which has the task of managing water and sanitation at the village level. In the management of water and sanitation facilities at the village level it is necessary to assess the performance so that it can be evaluated for future follow-ups for the strategy or position of the management group that has been included in the BUMDes Maju Lancar unit. This performance appraisal standard uses the performance appraisal standard from the 2020 Technical Guidelines for SPAMS Management. The results of the performance appraisal show that in general the performance of BPSPAMS Tirto Sumber Mulyo is in the medium category. Partially, it shows the performance of planning in the low category, in the high-performance administration and finance, on the performance of drinking water and sanitation services in the medium category and for the performance of the partnership in the low category. The hope in the future for improving the performance of BPSPAMS together with BUMDes Maju Lancar needs to collaborate or increase cooperation with external parties such as academics, practitioners and government institutions that can increase benefits and benefits for the public. Keywords: Planning, Administration, Finance, Services and Partnerships
\end{abstract}




\section{PENDAHULUAN}

Pembangunan masyarakat, menurut Dirjen Bangdes pada hakekatnya merupakan proses dinamis yang berkelanjutan dari masyarakat untuk mewujudkan keinginan dan harapan hidup yang lebih sejahtera dengan strategi menghindari kemungkinan tersudutnya masyarakat desa sebagai penanggung akses dari pembangunan regional atau daerah serta nasional. Pengertian tersebut mengandung makna, betapa pentingnya inisiatif lokal, partisipasi masyarakat sebagai bagian dari model-model pembangunan yang dapat mensejahterakan masyarakat desa (Soelaiman dalam Chairunisa, 2014).

Partisipasi merupakan proses dimana pihak-pihak yang terlibat mempengaruhi dan mengendalikan inisiatif pembangunan, keputusan dan sumber-sumber yang mempengaruhi mereka (Jennifer dkk dalam Chairunisa, 2014). Partisipasi memiliki sisi yang berbeda, bermula dari pemberian informasi dan metode konsultasi sampai dengan mekanisme untuk berkolaborasi dan pemberdayaan yang memberi peluang bagi stakeholder untuk lebih memiliki pengaruh dan kendali. Partisipasi juga dapat dikatakan berbagai corak tindakan masa maupun individual yang memperlihatkan adanya hubungan timbal balik antara Pemerintah dengan warganya

Secara umum corak partisipasi warga Negara dapat dibedakan menjadi empat macam: (Hamisi, 2013).

1. Partisipasi dalam pemilihan (electoral participation);

2. Partisipasi kelompok (group participation);

3. Kontak antara warga Negara dengan Pemerintah;

4. Partisipasi warga negara langsung.

Partisipasi masyarakat dapat diartikan sebagai pemberdayaan masyarakat, peran sertanya dalam kegiatan penyusunan perencanaan, dan implementasi program/proyek pembangunan dan merupakan aktualisasi dan kesediaan dan kemauan masyarakat untuk berkorban dan berkontribusi terhadap implementasi program pembangunan (Adisasmita 2006: 41). Dalam proses pembangunan, partisipasi berfungsi sebagai masukan dan keluaran. Sebagai masukan, partisipasi masyarakat berfungsi menumbuhkan kemampuan masyarakat untuk berkembang secara mandiri. Sebagai keluaran partisipasi dapat digerakkan atau dibangun. Disini partisipasi berfungsi sebagai keluaran proses stimulasi atau motivasi melalui berbagai upaya (Sularmi, 2009).

Setiap manusia memiliki hak untuk memperoleh akses terhadap air bersih dalam kuantitas dan kualitas yang diperlukan untuk memenuhi kebutuhan dasar mereka seperti 
Prosiding The 1st National Conference on Applied Business, Education, \& Technology (NCABET)"

Unversitas Bina Bangsa 2021

DOI Article : 10.46306/ncabet.v1i1.8

minum, memasak, dan keperluan rumah tangga yang mendasar (Gleick, 1999, dalam Trenggono dan Wahyono). Pada kenyataannya dewasa ini, masih banyak warga di seluruh Indonesia yang kesulitan mengakses air bersih karena keterbatasan infrastruktur yang ada. Kekurangan air bersih ini diantaranya disebabkan pada ketidakmampuan pemerintah melalui kementrian dalam pengelolaan, tanpa ada partisipasi ataupun kolabarosi dengan masyarakat dan kementrian lainnya (Trenggono dan Wahyono, 2017).

Program Penyediaan Air Minum dan Sanitasi Berbasis Masyarakat (Pamsimas) adalah salah satu program andalan Pemerintah untuk meningkatkan akses masyarakat pedesaan dan pinggiran terhadap fasilitas air minum dan sanitasi yang layak melalui pendekatan berbasis masyarakat (PAMSIMAS, 2016, dalam Trenggono dan Wahyono, 2017). Sebagai program stimulan dengan pendekatan berbasis masyarakat, Program Pamsimas menempatkan masyarakat sebagai pelaku utama dan sekaligus sebagai penanggungjawab pelaksanaan kegiatan. Program ini diharapkan dapat mejadi solusi bagi penyediaan air bersih perpipaan non PDAM yang melayani daerah-daerah yang masih belum dilayani oleh PDAM dan solusi dalam penyediaan layanan sanitasi yang layak serta praktek Perilaku Hidup Bersih dan Sehat (PHBS).

Pada tingkat desa/kelurahan, lembaga yang bertugas secara langsung dalam mengelola sistem penyediaan air minum terbangun dan kegiatan kesehatan adalah Badan Pengelola Sarana Penyediaan Air Minum dan Sanitasi (BPSPAMS). Lembaga ini dibentuk oleh masyarakat dan berperan dalam program mulai dari tahap perencanaan, pelaksanaan, sampai pengoperasian dan pemeliharaan serta dukungan keberlanjutan kegiatan program (PAMSIMAS, 2016). Dalam perkembangannya istilah Badan terjadi perubahan menjadi Kelompok. Pada pendirian atau badan hokum untuk BPSPAMS saat ini menjadi KPSPAMS, namun masih banyak istilah yang digunakan adalah BPSPAMS.

Pembangunan nasional merupakan usaha untuk meningkatkan seluruh aspek kehidupan bermasyarakat, berbangsa dan bernegara dan merupakan tujuan dari sistem penyelenggaraan negara. (Todaro, 2006). Aspek kehidupan bangsa yang meliputi aspek politik, ekonomi, sosial budaya, dan pertahanan keamanan secara berencana, menyeluruh, terarah, terpadu, bertahap dan berkelanjutan untuk memacu peningkatan kemampuan nasional dalam rangka mewujudkan kehidupan yang sejajar dan sederajat dengan bangsa lain yang lebih maju merupakan wujud dari pelaksanaan pembangunan. Pembangunan nasional adalah pencerminan kehendak untuk terus menerus meningkatkan kesejahteraan dan kemakmuran rakyat Indonesia (Jalunggono dan Destiningsih, 2018).

Air merupakan salah satu kebutuhan pokok manusia dan sangat diperlukan dalam meningkatkan kualitas kehidupan manusia dan pertumbuhan ekonomi suatu wilayah. 
Pemerintah Pusat dan Pemerintah Daerah Propinsi bertanggung jawab dan turut menjamin penyelenggaraan pelayanan public termasuk pelayanan air bersih. Undang-Undang No. 11 Tahun 1974 tentang Pengairan menyatakan bahwa air termasuk kekayaan alam yang terkandung didalamnya, mempunyai fungsi sosial serta digunakan untuk sebesar-besar kemakmuran rakyatnya (Nazar, dkk, 2018).

Pemenuhan kebutuhan air mulai menjadi prioritas dan diadopsi oleh negara-negara anggota PBB semenjak adanya deklarasi Millennium Development Goals (MDGs) pada September 2009 yang kemudian berlanjut menjadi agenda Sustainable Development Goals (SDGs) mulai tahun 2015. Pemerintah Indonesia sebagai negara yang ikut dalam agenda tersebut menempatkan tujuan itu sebagai salah satu prioritas penyediaan layanan dasar dalam pembangunan nasional. Pemerintah menargetkan dalam RPJMN 2015--2019 bahwa pada akhir tahun 2019 cakupan akses air minum layak secara menyeluruh di Indonesia mencapai 100\% (Universal Access) (Swastomo dan Iskandar, 2020).

Pengelolaan Prasarana Air Bersih Konsep Pengelolaan air bersih dan sumber air bersih pada dasarnya mencakup upaya pengembangan pemanfaatan dan pelestarian sumber daya air berupa menyalurkan air yang tersedia dalam konteks ruang, waktu, jumlah dan 17 mutu pada suatu wilayah untuk memenuhi kebutuhan pokok kehidupan masyarakat (Kodoatie, 2002, dalam Kholiq, 2014).

Menurut Permen PU nomor: 18/PRT/M/2007, tentang Penyelenggaraan pengembangan Sistem Penyediaan Air Minum (SPAM). Pengelolaan Sistem Penyediaan Air Minum pengelolaan SPAM meliputi kegiatan perencanaan, pelaksanaan, pengawasan serta pengoperasian dan pemanfaatan serta administrasi dan kelembagaan SPAM. Pengelolaan SPAM bertujuan untuk menghasilkan air minum yang sesuai dengan standar yang berlaku dan agar prasarana dan sarana air minum terpelihara dengan baik sehingga dapat melayani kebutuhan air minum masyarakat secara berkesinambungan. Standar pelayanan minimum air minum harus memenuhi ketentuan sesuai peraturan yang berlaku.

Pengelolaan SPAM dilaksanakan apabila prasarana dan sarana SPAM yang telah terbangun siap untuk dioperasikan dengan membentuk organisasi penyelenggara SPAM. Pembangunan prasarana dan sarana air minum harus simultan dengan pembentukan kelembagaan pengelola SPAM, sehingga ketika prasarana dan sarana air minum sudah siap beroperasi, telah terbentuk lembaga pengelola SPAM yang berbadan hukum.

Sedangkan khusus penyelenggara dari kelompok masyarakat tidak diharuskan berbadan hukum. Penyelenggara SPAM dapat melibatkan peran serta masyarakat dalam pengelolaan SPAM berupa pemeliharaan, perlindungan sumber air baku, penertiban 
Prosiding The 1st National Conference on Applied Business, Education, \& Technology (NCABET)"

Unversitas Bina Bangsa 2021

DOI Article : 10.46306/ncabet.v1il.8

sambungan liar, dan sosialisasi dalam penyelenggaraan SPAM. Pelibatan peran serta masyarakat dalam pengelolaan SPAM dapat difasilitasi oleh penyelenggara SPAM, antara lain melalui pembentukan forum pelanggan, pembentukan unit khusus yang mudah dihubungi untuk menampung keluhan dan laporan masyarakat mengenai pengelolaan SPAM, dan lainlain.

Dalam kegiatan penyediaan air bersih, diperlukan suatu organisasi yang bertugas menyelenggarakan tugas manajemen/pengelolaan. Organisasi tersebut dapat dipandang sebagai suatu sistem apabila didalamnya terjadi kegiatan. Untuk menjalankan fungsinya sebagai suatu sistem, diperlukan komponen-komponen untuk saling berinteraksi secara selaras. Komponen tersebut di sebut sebagai subsistem. Subsistem yang diperlukan dalam sistem penyediaan air bersih dapat dijabarkan sebagai berikut (Simatupang, 1995, dalam Kholiq, 2014) :

1. Subsistem organisasi dan manajemen, meliputi aspek bentuk organisasi, struktur organisasi, personalia (kualitas dan kuantitas), tata laksana kerja dan pendidikan serta latihan.

2. Subsistem teknik operasional, meliputi aspek tingkat penyediaan, lingkup wilayah yang terlayani, pos-pos penampungan air, pengaliran air beserta prasarana pendukungnya.

3. Subsistem pembiayaan dan retribusi/iuran, meliputi aspek sumber pendanaan, struktur pembiayaan, pola dan prosedur penarikan iuran dan struktur penentuan tarif iuran.

4. Subsistem pengaturan, meliputi aspek pembentukan aturan-aturan sebagai mekanisme kontrol terhadap sistem.

5. Sub sistem Peran Serta Masyarakat, meliputi keterlibatan masyarakat dalam penentuan jenis sumber air dan perencanaan, penentuan biaya pengelolaan, pemeliharaan sarana dan prasarana, pengawasan dan sangsi terhadap pelanggaran.

Pencapaian target penyediaan akses bagi seluruh masyarakat membutuhkan usaha dan kerja keras dari pemerintah dalam melakukan pembangunan layanan air. Pemenuhan layanan di pedesaan mulai menjadi prioritas dalam pembangunan wilayah yang sebelumnya lebih banyak ke perkotaan dibandingkan pedesaan. Salah satu program andalan pemerintah guna memenuhi kebutuhan layanan dasar yang tidak terlayani oleh sistem publik pada wilayah perdesaan adalah Program Penyediaan Air Minum Dan Sanitasi Berbasis Masyarakat (Pamsimas) (Swastomo dan Iskandar, 2020).

Keberlanjutan dapat diartikan sebagai upaya dan kegiatan penyediaan air minum dan penyehatan lingkungan yang dilakukan untuk dapat memberikan manfaat dan pelayanan kepada masyarakat pengguna secara terus menerus (Bappenas, 2003). Menurut Schuringa dalam 
Kamulyan, dkk (2017) sistem penyediaan air dikatakan berkelanjutan ketika : sistem itu berfungsi dan digunakan, sistem tersebut mampu memberikan tingkat manfaat yang sesuai (kualitas, kuantitas, keteraturan, kesediaan, efisiensi, kesetaraan, keandalan dan kesehatan), berjalan dalam jangka waktu yang lama tanpa berdampak buruk pada lingkungan, semua pembiayaan operasional dan pemeliharaan terpenuhi, terdapat lembaga yang mengelola, dan mendapat dukungan yang layak dari pihak luar. Aspek pada keberlanjutan untuk pembangunan air minum dan sanitasi terdapat 5 (lima) aspek, yaitu : teknis, sosial, keuangan, lingkungan, dan kelembagaan. Kelima aspek tersebut merupakan aspek yang saling mempengaruhi dan ketergantungan (Trijunianto, 2016)

Di Kecamatan Kebongung Kabupaten Demak terdapat 14 Badan Pengelola Sarana Air Minum dan Sanitasi (PSPAMS). 14 BPSPAMS tersebut semua berfungsi dalam operasional kepada masyarakat dalam beberapa kategori. Kategori - kategori terdiri dari mandiri (menguntungkan) ataupun dapat mengembangkan pengelolaan berdasarkan hasil perolehan dari biaya dari pelanggan atau masyarakat. Kategori lainnya adalah BPSPAMS hanya sekedar berjalan (masih impas). BPSPAMS juga dapat dibagi beberapa hal lagi, seperti kelengkapan pertanggungjawaban ke masyarakat yang difasilitasi Pemerintah Desa. Dari 14 BPSPAMS tesebut yang secara rutin mengadakan Rapat Akhir Tahun (laporan pertanggungjawaban) adalah sebanyak 4 BPSPAMS saja yang secara kontinyu melaporkan keuangannya.

BPSPAMS Tirto Sumber Mulyo (TSM) dari Desa Mijen merupakan salah satu BPSPAMS yang secara kontinyu melaporkan pengelolaan tersebut. Laporan tersebut berupa laporan keuangan, laporan pelanggan dan laporan di bidang Teknik. BPSPAMS Tirto Sumber Mulyo selama 6 tahun berturut - turut. Laporan akhir Tahun atau Laporan pertanggung jawaban tersebut hanya sekedar melaporkan sumber dan penggunaan dana yang diperoleh dari masyarakat, disamping juga laporan Teknik dan pelanggan. Dalam laporan yang disampaikan lebih ke terjadi penyimpangan atau tidak dalam pengelolaan.

BPSPAMS Tirto Sumber Mulyo selama ini tidak pernah melakukan pengukuran kinerja organisasi. Laporan pertanggung jawaban hanya berisi perkembangan pelanggan, perkembangan Teknik serta penggunakan dana yang diperoleh dari iuran pelanggan (masyarakat). Buku - buku laporan yang diperuntukkan untuk RAT adalah buku kas, buku bank, buku iuran, buku pelanggan, buku lain - lain, buku perkembangan saldo dan rugi laba bulanan. Secara umum BPSPAMS Tirto Sumber Mulyo dalam kategori berjalan lancar dan mandiri, akan tetepi masih belum dapat dikategorikan berkinerja baik atau tidak. Maksud dan tujuan untuk dilakukan pengukuran kinerja yang berdasarkan dari Juknis Pengelolaan SPAMS 
Prosiding The 1st National Conference on Applied Business, Education, \& Technology (NCABET)",

Unversitas Bina Bangsa 2021

DOI Article : 10.46306/ncabet.v1i1.8

dan Penguatan Keberlanjutan program Pamsimas adalah untuk persiapan pengelolaannya masuk dalam Unit BUMDes Maju Lancar.

\section{METODE PENELITIAN}

Tipe penelitian ini adalah diskriptif kuantitatif dengan pendekatan dari Petunjuk Teknis Pengelolaan SPAMS dan Penguatan Keberlanjtuan Program Pamsimas. Populasi yang dipilih adalah satu Organisasi BPSPAMS yaitu Tirto Sumber Mulyo. Jenis data yaitu kuantitatif berupa dokumentasi - dokumentasi dari BPSPAMS yang berupa Dokumen perencanaan, Pengelolaan Administrasi dan Keuangan, Kinerja Layanan Air Minum dan Sanitasi dan Kemitraan

Metode Analisis menggunakan deskriptif kuantitif dengan penggunakan tabel, prosentase dan indeks capaian. Pada kolom - kolom sudah tersedia pada metode ini dan tingkat skor sudah ditentukan. Alat penilaian kinerja BPSPAMS ini menggunakan lembar pantauan yang terdiri dari : (Juknis, 2020)

1. Dokumen perencanaan (Rencana Kerja) BPSPAMS/KPSPAMS

- $\quad($ tidak ada $=1 ;$ ada $=3)$

2. Pengelolaan Administrasi dan Keuangan yang terdiri dari

a. Pembukuan

1) tidak ada $=1$

2) ada, buku, kas, iuran, dan harian $=2$

3) lengkap, buku harian, iuran, kas dan laporan keuagna $=3$

b. Daftar invetaris/asset yang dikelola

1) Tidak ada $=1$

2) Ada $=3$

c. Iuran

1) Tidak ada $=1$

2) $\mathrm{Ada}=3$

d. Perbandingan iuran (I) dan Biaya operasional dan pemeliharaan

- $\quad \mathrm{I}<\mathrm{OP}=1$

- $\quad \mathrm{I} \geq \mathrm{OP}=2$

- $\quad \mathrm{I} \geq \mathrm{OP}$ dan pengembangan $=3$

3. Kinerja Layanan Air Minum dan Sanitasi

a. Kondisi sarana air minum yang berfungsi

1) $<40 \%$ (tidak berfungsi $)=1$

2) $40 \%-80 \%($ sebagian $0=2$

3) $>80 \%$ (berfungsi baik) $=3$

b. Jumlah penduduk yang sudah akses air minum yang layak saat ini 
1) $<40 \%$ (tidak berfungsi $)=1$

2) $40 \%-80 \%($ sebagian $0=2$

3) $>80 \%$ (berfungsi baik) $=3$

c. Jumlah pendudku dengna akses pada air minum berdasarkaan kapasaistas sitem air minum yang terbagun

1) $<40 \%$ (tidak berfungsi) $=1$

2) $40 \%-80 \%($ sebagian $0=2$

3) $>80 \%$ (berfungsi baik) $=3$

d. Jumlah penduduk yang belum akses air minum yang layak saat ini
1) $>60 \%=1$
2) $20 \% \mathrm{sd} 60 \%=2$
3) $<20 \%=3$

e. Jumlah penduduk dengan akses jamban sehat
1) $<40 \%=1$
2) $40 \% \mathrm{sd} 60 \%=2$
3) $>60 \%=3$

f. Jumlah dusuh telah mencapai SBS $100 \%$
1) $<40 \%=1$
2) $40 \% \mathrm{sd} 60 \%=2$
3) $>60 \%=3$

g. Jumlah dusun yang menerapkan CLTS
1) $<40 \%=1$
2) $40 \% \mathrm{sd} 60 \%=2$
3) $>60 \%=3$

4. Kemitraan

a. Rencana Kemitraan
1) Belum ada $=1$
2) Ada $=3$

b. Presentase realisasi kegiatan kemitraan terhadap rencana kemitraan /kerja sama
1) $<25 \%=1$
2) $25 \% \mathrm{sd} 50 \%=2$
3) $>50 \%=3$

Analisis Hasil Pengukuran (Skala Kinerja) :

- Total Nilai < 23 : kinerja rendah

- Total Nilai 23-32: Sedang

- Total nilai $>32$ : Kinerja tinggi

\section{HASIL DAN PEMBAHASAN}

\section{Kinerja Perencanaan}

Tabel 1 : Penilaian Kinerja pada Bidang Perencanaan 
Prosiding The 1st National Conference on Applied Business, Education, \& Technology (NCABET)"

Unversitas Bina Bangsa 2021

DOI Article : $10.46306 /$ ncabet.v1i1.8

\begin{tabular}{|l|l|c|c|c|l|}
\hline \multirow{2}{*}{ No } & Dokumen Perencanaan & \multicolumn{3}{|c|}{ Kondisi Real BPSPAMS } & \multirow{2}{*}{ Ket } \\
\cline { 3 - 5 } & & Tidak ada (1) & Sedang & Tinggi (3) & \\
\hline 1 & $\begin{array}{l}\text { Rencana Kerja } \\
\text { (investasi) BPSPAMS }\end{array}$ & $\sqrt{ }$ & & Rendah \\
\hline
\end{tabular}

Sumber : Data sekunder yang diolah

Berdasarkan tabel 1 datas menunjukan bahwa BPSPAMS Tirto Sumber Mulyo selama ini investasi - investasi tidak pernah direncanakan atau dibukukan secara matang. Pembangunan atau pengembangan yang dilakukan selama ini hanya berupa perkiraan saja. Tidak ada Rencana anggaran biaya (RAB) atau gambar yang berdasarkan pertimbangan teknis. Misalkan pada tahun 2016 membangun bak air denga kapasitas $180 \mathrm{~m}^{3}$ tanpa ada gambar dan RAB. Akibatnya pada perjalanan pembangunan mengalami kendala, yaitu kekurangan biaya. Untuk menutup biaya - biaya tersebut menggunakan hutang atau memanfaatkan pinjaman. Hal ini kurang bagus dan dapat mengganggu stabilitas keuangan atau likuiditas dari BPSPAMS, karena kewajiban jangka pendek justru dapat terganggu. Kondisi ini juga dijadikan tolok ukur atau peringatan dini dari BUMDes Maju Lancar dalam menilai perencanaan dari BPSPAMS TSM

\section{Pengelolaan Administrasi dan Keuangan}

Tabel 2 : Pengelolaan Administrasi dan Keuangan

\begin{tabular}{|l|l|c|c|c|c|}
\hline \multirow{2}{*}{ No } & Pengelolaan Administrasi dan & \multicolumn{3}{|c|}{ Kondisi Real BPSPAMS } & Ket \\
\cline { 2 - 5 } & Keuangan & Tidak ada (1) & Sedang (2) & Tinggi (3) & \\
\hline 1 & Pembukuan & $\mathrm{X}$ & $\mathrm{X}$ & Lengkap & Tinggi \\
\hline 2 & Daftar Inventaris & $\mathrm{X}$ & $\mathrm{X}$ & $\mathrm{Xda}$ & Tinggi \\
\hline 3 & Iuran & $\mathrm{X}$ & $\mathrm{X}$ & $\begin{array}{c}\text { Iuran }> \\
\text { Operasional }\end{array}$ & Tinggi \\
\hline 4 & $\begin{array}{l}\text { Perbandingan Iuran dengan } \\
\text { Operasional }\end{array}$ & & & & \\
\hline
\end{tabular}

Sumber : Data sekunder yang diolah

Penilaian kinerja di aspek pembukaan dalam kategori yang tinggi, dimana pembukuan BPSPAMS Tirto Sumber Mulyo termasuk sudah lengkap dan terstandar (sesuai pedoman). Daftar inventaris berkenaan dengan mesin, gedung dan peralatan juga tercatat secara lengkap. Bahkan pada tahun 2021 ini asset yang ada dihitung depresiasi atau penyusutannya dari harga perolehan. Buku iuran tersedia secara lengkap dan rapi, namun untuk upaya penagihan belum dapat dilakukan secara maksimal. Perbandingan iuran dengan operational sudah dilakukan dengan baik melalui buku rugi laba. Dalam waktu satu bulan berjalan, BPSPAMS Tirto Sumber Mulyo langsung dapat mengetahui pada posisi rugi atau laba. Kinerja yang baik ini dapat dijadikan perbandingan atau acuan untuk unit - unit BUMDes yang lainnya.

\section{Kinerja Layanan Air Minum dan Sanitasi}


Tabel 3 : Kinerja Layanan Air Minum dan Sanitasi

\begin{tabular}{|l|l|c|c|c|c|}
\hline \multirow{2}{*}{ No } & Aspek yang dinilai & \multicolumn{3}{|c|}{ Kondisi Real BPSPAMS } & Ket \\
\cline { 3 - 5 } & $\begin{array}{c}\text { Tidak ada } \\
(1)\end{array}$ & Sedang (2) & Tinggi (3) & \\
\hline 1 & $\begin{array}{l}\text { Kondisi sarana air minum yang } \\
\text { berfungsi }\end{array}$ & $\mathrm{X}$ & $\mathrm{X}$ & $\begin{array}{l}>80 \%- \\
100 \%\end{array}$ & Tinggi \\
\hline 2 & $\begin{array}{l}\text { Jumlah penduduk yang sudah akses } \\
\text { air minum yang layak saat ini }\end{array}$ & $\mathrm{X}$ & $40-80$ & $\mathrm{X}$ & Sedang \\
\hline 3 & $\begin{array}{l}\text { Jumlah Penduduk dengan akses pada } \\
\text { air minum berdasarkan kapasitas } \\
\text { system air minum yang terbangun. }\end{array}$ & $<40 \%$ & $\mathrm{X}$ & $\mathrm{X}$ & Rendah \\
\hline 4 & $\begin{array}{l}\text { Jumlah Penduduk yang belum Akses } \\
\text { air minum yang layak saat ini }\end{array}$ & $\mathrm{X}$ & $20-60 \%$ & $\mathrm{X}$ & Sedang \\
\hline 5 & $\begin{array}{l}\text { Jumlah penduduk dengan akses } \\
\text { jamban sehat }\end{array}$ & $\mathrm{X}$ & $\mathrm{X}$ & $>60 \%$ & Tinggi \\
\hline 6 & $\begin{array}{l}\text { Jumlah Dusun telah mencapai SBS } \\
100 \%\end{array}$ & $\mathrm{X}$ & $40-60 \%$ & $\mathrm{X}$ & Sedang \\
\hline 7 & Jumlah dusun yang menerapkan CTPS & $\mathrm{X}$ & $40-60 \%$ & $\mathrm{X}$ & Sedang \\
\hline & \multicolumn{2}{|l|}{} & & & \\
\hline
\end{tabular}

Sumber : Data sekunder yang diolah

Berdasarkan tabel 3 diatas menunjukkan kinerja pada kondisi air minum yang dapat berfungsi secara maksimal. Peralatan yang dimiliki dan sarana untuk mendukung penyediaan air bersih tersebut dapt difungsikan secara maksimal. Jumlah penduduk yang sudah mengakses air minum yang layak saat ini pada kategori sedang (40\%-80\%). Wilayah mijen dilewati beberapa sungai kecil, akibatnya beberapa sumur warga terdapat air, namun perilaku sebagian masyarakat yang masih membuang sampah, akibatnya air sumur ada yang tercemar.

Jumlah Penduduk dengan akses pada air minum berdasarkan kapasitas system air minum yang terbangun masih dalam kategori yang rendah (kurang $40 \%$ ). Masih ada beberapa masyarakat yang memanfaatkan air sumur baik milik sendiri atau tetangga. Alasan yang sering muncul adalah kualitas air dari BPSPAMS masih belum konsisten. Apabila air baku keruh, maka air hasil olahan melalui instalasi pengolahan air sederhana (IPAS) juga tidak dapat jernih (keruh). Hal ini berdampak pada beberapa warga atau penduduk masih menggunakan air sumur, meskipun penduduk tersebut ada yang menjadi pelanggan BPSPAMS.

Jumlah penduduk yang belum mengaksses air minum yang layak saat ini mencapai 20 - $60 \%$ atau dalam kategori berkinerja sedang. Ada beberapa alasan kenapa warga atau penduduk yang belum menggunakan air minum yang layak saat ini, diantaranya ketersediaan air mandiri (sumur) yang masih melimpah. Jumlah penduduk yang akses jamban sehat dalam kategori yang tinggi (lebih $60 \%$ ). Kinerja pada Stop buang air besar sembarangan (SBS) masih kategori sedang. Hal ini terjadi karena sebagian penduduk sebagian bercocok tanam. 
Prosiding The 1st National Conference on Applied Business, Education, \& Technology (NCABET)"

Unversitas Bina Bangsa 2021

DOI Article : 10.46306/ncabet.v1i1.8

Kondisi ini membuat masih ada perilaku SBS, karena pada saat bersamaan posisi sedang di sawah. Kinerja pada cuci tangan pakai sabun (CTPS) masih dalam kategori yang sedang (40\%- $60 \%)$. Hal ini menunjukkan bahwa kinerja layanan air minum dan sanitasi secara umum dalam kategori yang sedang. Perlu sinergitas antara masyarakat, pemerintah desa dan tokoh masyarakat untuk meningkatkan kinerja layanan air minum dan sanitasi. BUMDes dapat mengambil prakarsa untuk kedepannya dalam upaya peningkatan kualitas layanan dengan kewenangan yang diberikan untuk melakukan konsolidasi dengan berbagai unsur di masyarakat ataupun dengan Pemrintahan Desa. Kinerja Kemitraan

Tabel 4 : Kinerja Kemitraan

\begin{tabular}{|l|l|c|c|c|c|}
\hline \multirow{2}{*}{ No } & Aspek yang dinilai & \multicolumn{2}{|c|}{ Kondisi Real BPSPAMS } & Ket \\
\cline { 3 - 6 } & Tidak ada (1) & $\begin{array}{c}\text { Sedang } \\
(2)\end{array}$ & Tinggi (3) & \\
\hline 1 & Rencana kemitraan & Belum ada & $\mathrm{X}$ & $\mathrm{X}$ & Rendah \\
\hline 2 & $\begin{array}{l}\text { Persentase realisasi kegiatan } \\
\text { kemitraan terhadap rencana } \\
\text { kemitraan }\end{array}$ & $<25 \%$ & $\mathrm{X}$ & $\mathrm{X}$ & Rendah \\
\hline
\end{tabular}

Sumber : Data sekunder yang diolah

Berdasarkan tabel 4 menunjukkan bahwa BPSPAMS Tirto Sumber Mulyo selama 8 tahun beroperasi belum mempunyai rencana kemitraan dengan pihak dari unsur internal ataupun dari unsur eksternal. Hal ini menunjukkan bahwa kinerja pada kemitraan tergolong berkinerja rendah (belum ada rencana). Pada aspek persentase realisasi kegiatan kemitraan terhadap rencana kemitraan dalam kategori rendah ( kurang $25 \%$ ). Kondisi ini menunjukkan bahwa BPSPAMS belum memaksimalkan potensi - potensi yang ada, sehingga peluang peluang untuk peningkatan kinerja ataupun untuk memuaskan pelanggan atau masyarakat belum dapat dilakukan secara maksimal. BUMDes Maju Lancar dapat memberikan arahan ataupun konsultasi terkait kemitraan - kemitraan yang dapat meningkatkan keuntungan dan manfaat bagi masyarakat.

Secara umum kinerja BPSPAMS Tirto Sumber Mulyo dalam kategori yang cukup atau sedang. Hal ini ditandai dengan point atau skor nya adalah 30, dimana nilai tersebut diantara 23 sampai dengan 32. Kinerja yang dalam kategori tinggi adalah pada kinerja dalam pengelolaan administrasi. Pada layanan air minum dan sanitasi secara umum mempunyai kinerja yang cukup. Pada bagian ini hanya ada 2 aspek yang tinggi yaitu pada kondisi sarana air minum yang berfungsi dan akses jamban sehat. Aspek lainnya pada layanan ini adalah pada kategori yang sedang. Bahkan masih ada Penduduk dengan akses pada air minum berdasarkan kapasitas system air minum yang terbangun. Pada aspek perencanaan dan kemitraan masih dalam kategori yang rendah. BUMDes sebagai pihak yang menjadi pengawas atau dari 
BPSPAMS Tirto Sumber Mulyo yang awalnya adalah kelompok mandiri diharapkan transparansi, akuntanbilitas serta kinerja juga dapat meningkat.

\section{KESIMPULAN}

Berdasarkan hasil pembahasan dapat diberikan saran adalah pihak BPSPAMS Tirto Sumber Mulyo perlu merumuskan atau memberikan pembagian tugas - tugas yang lebih jelas kepada para anggota atau seksi - seksi yang ada pada kelompok pengelola ini. Pihak BPSPAMS dengan dibantu BUMDes Maju Lancar perlu berkolaborasi atau minigkatkan kerjasama dengan pihak - pihak eksternal seperti pihak akademisi atau praktisi berkaitan bagaimana menyusun perencanaan dan Rencana Anggara Biaya.

Berkolaborasi (belajar) dengan pihak PDAM dan Dinas Kesehatan Kota untuk meingkatkan hasil olahan air bersih (minum) baik dari segi kualitas ataupun dari segi kesehatannya. BPSPAMS juga perlu melakukan kolaborasi atau bekerja sama dengan berbagai pihak baik dari sisi pendanaan (perbankan atau Lembaga pembiayaan) atau dengan pihak eksternal lainnya untuk mengembangkan produk yang ada dengan teknologi untuk memproduksi air bersih lainnnya (misalkan dengan menjual air isi ulang).

\section{UCAPAN TERIMAKASIH}

Terima kasih kepada Ketua Badan Pengelola Sarana Penyediaan Air Minum dan Sanitasi (BPSPAMS) Tirto Sumber Mulyo yang dijadikan obyek penelitian. Semua Perangkat dari Pemerintah Desa Mijen Kecamatan Kebonagung Kabupaten Demak. Semua pihak yang berkontribusi pada karya ilmiah ini.

\section{DAFTAR PUSTAKA}

Badan Perencanaan Pembangunan Nasional. 2003. Kebijakan Nasional Pembangunan Air Minum dan Penyehatan Lingkungan Berbasis Masyarakat. Badan Perencanaan Pembangunan Nasional. Jakarta

Chaerunnissa, C. 2014. Partisipasi Masyarakat Dalam Program Penyediaan Air Minum dan Sanitasi Berbasis Masyarakat (Pamsimas) di Kabupaten Brebes (Studi Kasus Desa Legok dan Desa Tambakserang Kecamatan Bantarkawung) POLITIKA, Vol. 5 (2) : 24 -35 .

Hamisi, F.N. 2013. Partisipasi Politik Masyarakat Dalam Pembuatan Kebijakan (Suatu Studi terhadap Musyawarah Rencana Pembangunan Di Kecamatan Jailolo). Journal Unsrat, Vol 5 (1) : 1 - 17 
Prosiding The 1st National Conference on Applied Business, Education, \& Technology (NCABET)"

Unversitas Bina Bangsa 2021

DOI Article : 10.46306/ncabet.v1i1.8

Jalunggono, G dan Destiningsih, R. 2018., Model Pemberdayaan Dan Evaluasi Program Penyediaan Air Minum Berbasis Masyarakat (Pamsimas) Studi Kasus Pada Badan Pengelola Sarana Pengadaan Air Minum Dan Sanitasi (Bp-Spams) Andanawarih Desa Sudimara Kecamatan Cilongok Kabupaten Banyumas., Jurnal Pemberdayaan., Vol 3 (2) : 574 - 588 .

Kamulyan, P. Wiguna, I.P.A. dan Slamet, A. (2017). Penilaian Keberlanjutan Pengelolaan Sistem Penyediaan Air Minum Berbasis Masyarakat di Kota Blitar. Insitut Teknologi Sepuluh November Journal Of Civil Engineering. Vol 32 (2) : 6 - 68.

Kholiq, A. 2014. Evaluasi Keberhasilan Program Air Minum dan Sanitasi (Pamsimas) di Kabupaten Tegal dan Kabupaten Brebes., Jurnal Ilmu dan Terapa Bidang Teknik Sipil. Vol $20(2): 125-133$

Kodoatie, Robert J., 2003. Pengantar Manajemen Infrastruktur, Pustaka Pelajar, Yogyakarta

Maryati, S., Rahmani, N. I., \& Rahajeng, A. S., 2018., Keberlanjutan Sistem Penyediaan Air Minum Berbasis Komunitas (Studi Kasus: HIPPAM Mandiri Arjowinangun, Kota Malang). Jurnal Wilayah dan Lingkungan, vol 6 (2) : 131 - 147

Petunjuk Teknis Pengelolaan SPAMS dan PEnguatan Keberlanjutan Program Pamsimas, 2020., Dirjen Pengembangan Sistem Penyediaan Air Minum.

Swastomo, A.S dan Iskandar, D.A. 2021. Keberlanjutan Sistem Penyediaan Air Minum Pedesaan Berbasis Masyarakat. Jurnal Litbang Sukowati In Press. Vol. 4 (2) : 12 - 25

Sularmi, S. 2009. Sikap Petani Wortel (Daucus Carota) terhadap Pengembangan Kawasan Agropolitan Di Kecamatan Tawangmangu Kabupaten Karanganyar. Jurnal Ekonomi Pertanian., Vol 3 (3) : 14 - 29

Todaro M.P. 2006. Pembangunan Ekonomi di Dunia Ketiga, Penerbit Erlangga,Jakarta Nazar, T. Moch., Azmeri, Fatimah., 2018., Evaluasi Keberhasilan Pengelolaan Program Penyediaan Air Minum dan Sanitasi Berbasismasyarakat di Kabupaten Aceh Besar., Jurnal Teknik Sipil., Universitas Syiah Kuala., Vol 1 Special Issue (4) : 75 - 87.

Trenggono, F.C. dan Wahyono, H. 2017. Persepsi Masyarakat Mengenai Kinerja Pelayanan PAMSIMAS di Kota Semarang., Jurnal Pembangunan Wilayah dan Kota., Vol 13 (4) : $411-423$.

Trijunianto, O. 2016., Analisis Faktor Keberlanjutan Sarana Air Minum Program Pamsimas di Kabupaten Kupang Provinsi Nusa Tenggara Timur., Tesis., Institut Teknologi Sepuluh Nopember : 1 - 85 . 